\title{
Badania kopalnego DNA - możliwości i ograniczenia
}

\author{
Tomasz Wasiak*, Tadeusz Strózik
}

Zakład Biologii Molekularnej, Katedra Biologii Medycznej, Uniwersytet Medyczny w Łodzi

Abstrakt

Ostatnie cztery dekady przyniosły znaczący rozwój archeologii molekularnej i badania nad kopalnym DNA (aDNA). Nowatorskie metody uwzględniają szeroki zakres badań, począwszy od sekwencjonowania niewielkich fragmentów mitochondrialnego DNA po wielkoskalowe badania całych populacji, łączące sekwencjonowanie genomów mitochondrialnych, genów podlegających doborowi naturalnemu, jak i całych genomów jądrowych. Postęp, zwłaszcza w dziedzinie technologii sekwencjonowania DNA, umożliwił pozyskanie informacji ze szczątków paleontologicznych i materiału archeologicznego, umożliwiając zbadanie związków filogenetycznych między wymarłymi i współczesnymi gatunkami. Dzięki zastosowaniu technologii sekwencjonowania nowej generacji możliwe stało się poznanie sekwencji DNA nie tylko bezpośrednio ze szczątków ludzkich lub zwierzęcych, ale także z osadów sedymentacyjnych z głębin jezior oraz jaskiń. W artykule przedstawiono możliwości i ograniczenia występujące w badaniach nad kopalnym DNA ludzi, zwierząt czy bakterii z podkreśleniem wkładu polskich badaczy w rozwój tej dziedziny nauki.

Słowa

kluczowe

kopalny DNA • NGS • mamut włochaty • neandertalczyk • prątek trądu • prątek gruźlicy • pałeczka dżumy

Otrzymano: 13.11.2020, Zaakceptowano: 14.07.2021

Abstract

The last four decades has brought significant development in the field of molecular archaeology and ancient DNA (aDNA). The novel methods cover a wide spectrum of research, ranging from the reconstruction of small fragments of mitochondrial DNA to large-scale studies of entire populations, combining sequencing of mitochondrial genomes, genes subjected to natural selection and entire nuclear genomes. Progress, particularly in the field of DNA sequencing technology, has made it possible to obtain information from paleontological and archaeological remains, thereby allowing us to examine the relationship between extinct and contemporary species. By introduction next-generation sequencing, it has become possible to recognize DNA sequence not only directly from remains but also from sediments from the depths of lakes and caves. This publication aims to provide the reader with knowledge about the possibilities and limitations of studies on human, animals and bacterial ancient DNA, as well as polish contribution to the development of this field of science.

\section{Keywords}

ancient DNA • NGS • woolly mammoth • Neanderthal • Mycobacterium leprae Mycobacterium tuberculosis • Yersinia pestis

Received: 13.11.2020, Accepted: 14.07.2021

*Corresponding author e-mail: tomasz.wasiak@umed.lodz.pl

(a) BY-Nc-ND ( 2021 Tomasz Wasiak, Tadeusz Strózik, This work is licensed under the Creative Commons Attribution-NonCommercial-NoDerivs 4.0 License. 


\section{Problematyka badań i analizy kopalnego DNA}

Pośmiertne przemiany materiału genetycznego to główny problem w metodyce badań nad kopalnym DNA. Kwas deoksyrybonukleinowy (DNA) jest cząsteczką, która stosunkowo łatwo ulega degradacji. W aktywnych metabolicznie komórkach uszkodzenia DNA są identyfikowane i usuwane przez procesy naprawcze [1]. W komórkach nieaktywnych metabolicznie (nekrotycznych) [2] i w komórkach będących na nieodwracalnych etapach procesu apoptozy [3] dochodzi do gromadzenia nienaprawionych uszkodzeń DNA. Już pierwsze badania systemowe nad kopalnym DNA wskazały na fragmentację materiału genetycznego na odcinki o długościach 40-500 par zasad (pz) [4]. Fragmentacja materiału genetycznego po śmierci jest początkowo wynikiem aktywności enzymatycznej obumierających komórek, a następnie bakterii, grzybów, roślin i owadów rozkładających materię organiczną. $\mathrm{Na}$ proces fragmentacji DNA mogą mieć wpływ zachodzące w glebie nieenzymatyczne reakcje hydrolitycznego rozrywania wiązań fosfodiestrowych i N-glikozydowych (ryc. 1A) [5]. Narażone na uszkodzenia są przede wszystkim zakończenia łańcucha DNA. W badaniach nad genomowym DNA szczątków neandertalczyka wykazano zwiększoną zawartość puryn na końcach fragmentów łańcucha DNA [6]. W szczątkach plejstoceńskiego konia, zakonserwowanego w wiecznej zmarzlinie, wykazano ponadto zwiększoną zawartość guaniny w stosunku do adeniny [7]. Preferencyjne usuwanie guaniny $\mathrm{z}$ łańcucha nukleotydowego wyjaśnia struktura rezonansowa tej puryny. $W$ przeciwieństwie do adenozyny, delokalizacja elektronu między atomem azotu (N9) i tlenu (przy węglu C6) w guanozynie, powoduje obniżenie energii aktywacji wymaganej do zerwania wiązania N-glikozydowego [8]. Hydrolityczne usunięcie zasady azotowej oraz związany $z$ nią proces $\beta$-eliminacji może doprowadzić do powstawania pęknięć pojedynczej nici cząsteczki DNA. Wytworzone w ten sposób miejsca apirymidynowe jak i apurynowe hamują syntezę komplementarnej nici DNA w PCR, ponieważ stosowane powszechnie polimerazy nie rozpoznają i nie namnażają tak zmodyfikowanych fragmentów [9] (ryc. 1B).

Proces hydrolitycznej deaminacji (miscoding lession) zachodzący w cząsteczce DNA prowadzi do chemicznych modyfikacjizasad azotowych, utrudniając badania molekularne kopalnego DNA. Najczęściej procesowi temu ulega cytozyna przekształcana do uracylu. Jeśli tak powstały uracyl znajdzie się na nici wiodącej, to polimeraza DNA na nici opóźnionej zamiast guaniny wstawi adeninę (uracyl odczytywany jest jako tymina) [10]. Procesowi deaminacji może ulegać też adenina, w wyniku którego powstaje hipoksantyna. Hipoksantyna odczytywana jest jako guanina i w produkcie namnażania powoduje zmianę w postaci tranzycji A/G lub T/C

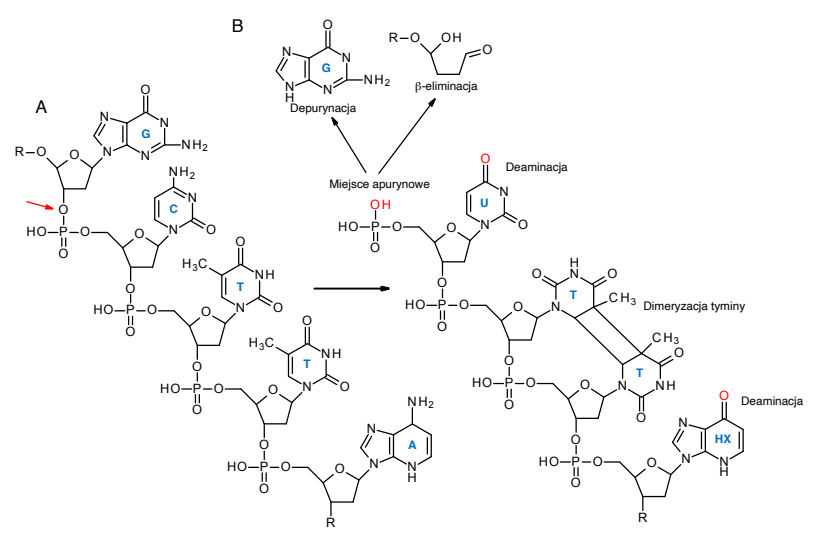

Rycina 1. A - Pojedyncza nić cząsteczki DNA oraz B - charakterystyczne uszkodzenia i modyfikacje kopalnego DNA. Czerwoną strzałką oznaczono miejsce hydrolitycznego cięcia wiązania fosfodiestrowego. Skróty A, C, G, HX, T, U oznaczają odpowiednio adeninę, cytozynę, guaninę, hipoksantynę, tyminę, uracyl.

[11]. Innym typem uszkodzeń aDNA jest tworzenie się wiązań krzyżowych na jednej nici DNA, między różnymi fragmentami DNA oraz między DNA a innymi molekułami. Wiązania te są zawadą przestrzenną dla polimerazy DNA, a to zatrzymuje proces amplifikacji [12].

$\mathrm{Na}$ trwałość aDNA w naturalnym środowisku ma wpływ wiele czynników, takich jak wilgotność, zasolenie, $\mathrm{pH}$, promieniowanie elektromagnetyczne czy temperatura. Okres półtrwania fragmentu mitochondrialnego DNA (mtDNA) o długości 242 pz oszacowany został na 521 lat dla temperatury $5^{\circ} \mathrm{C}$, a wraz ze wzrostem temperatury okres półtrwania ulega znacznemu skróceniu [13]. Najstarsze wiarygodne próbki aDNA pochodzą z trzech zębów mamutów odnalezionych na Syberii. Wiek badanych preparatów oszacowano na 1,28 mln lat oraz 0,62 mln lat [14]. Badania nad starzeniem się DNA nie wskazały zależności między stopniem fragmentacji DNA a wiekiem materiału kopalnego. Zaobserwowano natomiast zależność między wiekiem szczątków a pojawianiem się puryn na końcu 5' łańcucha aDNA. W próbkach młodszych niż 100 lat dominowały reszty adeniny, a w próbkach starszych niż 40 tys. lat dominowały reszty guaniny [15].

Zanieczyszczenie egzogennego DNA pochodzącego ze środowiska to duży problem w badaniach kopalnego DNA. Zaliczyć tu można DNA bakteryjny, roślinny oraz ludzki należący do osób zajmujących się wydobyciem i analizą materiału kopalnego i przez to nazywane jest egzogennym DNA [16]. Wyróżnić można co najmniej cztery potencjalne źródła zanieczyszczeń aDNA.

- Kopalny DNA izolowany jest głównie z kości i zębów, które spoczywają w glebie na różnych głębokościach. Materiał wyizolowany z takiego środowiska będzie mieszaniną DNA wszystkich organizmów zamieszkujących daną niszę 
ekologiczną. Pomimo rygorów postępowania z materiałem kostnym [17] endogenny aDNA stanowi zwykle niewielki odsetek całkowitego wyizolowanego DNA. Przykładowo dla szczątków dziecka z Mal'ta nad Bajkałem zawartość endogennego DNA wynosiła 4\% [18], a dla szczątków neandertalczyka 1-5\% [19].Zwykle ponad 95\% wyizolowanego DNA należy do mikroorganizmów kolonizujących szczątki [20]. Bakterie, uwalniając produkty metabolizmu, zwiększają porowatość kości i zębów, przyczyniając się do ekspozycji aDNA na środowisko wodne, powodując tzw. wyciekanie materiału genetycznego badanego osobnika [21].

- Zanieczyszczenie materiału kostnego może nastąpić podczas prac wykopaliskowych $z$ winy archeologów wydobywających i przygotowujących materiał kopalny do badań. Materiał archeologiczny przeznaczony do analizy genetycznej, aby ograniczyć jego degradację do minimum, powinien być pobierany i przechowywany $w$ ten sam sposób, w jaki pobiera się rutynowo materiał do badań biologicznych [22].

- Materiał kostny może zostać zanieczyszczony egzogennym DNA w warunkach muzealnych. Autentykacja DNA pozyskanego $z$ eksponatów muzealnych wiąże się $z$ trudnością $z$ odróżnieniem endogennego od egzogennego DNA, gdyż ten ostatni może ulegać podobnej degradacji do kopalnego DNA [23].

- Zanieczyszczenia mogą pochodzić z odczynników chemicznych użytych do izolowania DNA i przygotowywania biblioteki fragmentów DNA. Jest to zdecydowanie najrzadziej występujący rodzaj zanieczyszczeń, choć mieliśmy z nim do czynienia. Wśród zanieczyszczeń odczynników wymienić należy DNA pochodzący od osób przygotowujących odczynniki oraz fragmenty genomów wirusów i bakterii wykorzystywanych do pozyskiwania metodą inżynierii genetycznej enzymów wykorzystywanych w analizie aDNA.

Powszechnie stosowaną metodą umożliwiającą pozbycie się egzogennego DNA jest inkubacja przez 15-60 min materiału kopalnego w 3-6\% wodnym roztworze podchlorynu sodu, $\mathrm{NaOCl}$ [24]. Płukanie w $\mathrm{NaOCl}$ sproszkowanych elementów kostnych pozostawia bez uszczerbku endogenny DNA. Dłuższe i bardziej wrażliwe fragmenty egzogennego DNA ulegają degradacji [25].

Ważnym czynnikiem zmniejszającym ryzyko zanieczyszczenia próbki egzogennym DNA jest wybór do badań odpowiednich kości lub fragmentów szkieletu. Najczęściej do izolowania aDNA wykorzystuje się zęby. $W$ razie braku zębów można wykorzystać inne elementy szkieletu, a zwłaszcza kość skalistą, która zawiera statystycznie najwięcej endogennego DNA [26]. Ponadto wybiera się fragmenty szkieletu 0 najmniej gąbczastej strukturze. Zawartość endogennego DNA jest pozytywnie skorelowana z gęstością kości, co udało się potwierdzić dzięki skanom tomografii komputerowej (TK) materiału kopalnego [27]. Tomografia komputerowa jest powszechnie stosowaną metodą obrazowania pozwalającą na dokładny pomiar gęstości tkanek. W archeologii i paleontologii jest używana do nieinwazyjnego obrazowania trójwymiarowego wewnętrznej i zewnętrznej struktury obiektów. Ponadto połączenie technik obrazowania TK i druku 3D pozwala na odtworzenie ubytków skamieniałości [28].

\section{Krótka historia badań nad kopalnym DNA}

Za początek badań nad kopalnym DNA można przyjąć opublikowane w 1984 r. przez Russa Higuchi wyniki badań nad wyizolowaniem i namnożeniem mtDNA wymarłej pod koniec XIX w. kwagi (Equus quagga quagga) [29] oraz opublikowane rok później przez Svante Pääbo, który sekwencjonował fragment DNA o długości 3400 pz pozyskany z egipskiej mumii [30]. Jest to okres, który zbiegł się w czasie z pierwszymi próbami opracowania techniki łańcuchowej reakcji polimerazy (PCR). W zacytowanych wyżej badaniach wykorzystano technikę klonowania bakterii do namnażania krótkich sekwencji DNA i z czasem wykazano, że źródło wyekstrahowanego i sekwencjonowanego materiału genetycznego jest pochodzenia mikrobiologicznego, a nie kopalnego. Poodkryciu i upowszechnieniu technik PCR i sekwencjonowania DNA metodą Sangera (sekwencjonowanie pierwszej generacji) rozpoczął się gwałtowny rozwój archeologii i paleontologii molekularnej. Niestety ukazało się również wiele publikacji opisujących pozyskiwanie kopalnego mtDNA ze szczątków dinozaurów liczących nawet dziesiątki milionów lat [31] czy bakterii halofilnych sprzed $250 \mathrm{mln}$ lat [32]. Opublikowane wyniki były najprawdopodobniej rezultatem amplifikacji egzogennego DNA.

Od czasu pionierskich badań z początku lat $80 \mathrm{XX}$ w. techniki izolowania i namnażania aDNA były ciągle modyfikowane i ulepszane. Wieloletnie badania i zdobyte doświadczenie pozwoliło na pokonanie dwóch głównych ograniczeń metodologicznych: obecność egzogennego DNA oraz niską jakość endogennego DNA. Ulepszona metodyka oparta była na trzech filarach:

- namnażaniu techniką PCR fragmentów DNA o długości od 60 do $200 \mathrm{pz}$,

- namnażaniu i sekwencjonowaniu kilku klonów każdego badanego fragmentu DNA,

- dopasowywaniu i porównywaniu sekwencji DNA pozyskanych $z$ różnych klonów i różnych nakładających się fragmentów, w celu uzyskania ostatecznej sekwencji badanego regionu.

Korzystając z powyższej metodyki Matthias Krings w 1997 r. uzyskał sekwencje dwóch fragmentów genomu 
mitochondrialnego neandertalczyka (Homo sapiens neanderthalensis) [33, 34]. Prace te zapoczątkowały wiele badań kopalnego DNA ukierunkowanych na różne fragmenty genomu mitochondrialnego. W zależności od danej tkanki komórka zawiera od kilkuset do kilkudziesięciu tysięcy kopii mtDNA. Genom mitochondriów nie podlega rekombinacji, a mutacje są przenoszone $z$ pokolenia na pokolenie w linii matczynej i mogą być wykorzystywane do ustalania pochodzenia danych osobników [35]. Pozwoliło to np. na odtworzenie zależności filogenetycznych między współcześnie istniejącymi i wymarłymi gatunkami zwierząt, takich jak mamut włochaty [36] czy tur, którego pełny genom mitochondrialny został zsekwencjonowany przez polskich uczonych z Uniwersytetu Przyrodniczego w Poznaniu [37].

Pierwsza dekada XXI w. przynosi dalszy rozwój metod pozyskiwania i analizy aDNA, a przełomem było upowszechnienie się metody sekwencjonowania drugiej generacji (NGS) zwanej również sekwencjonowaniem wysokoprzepustowym, HTS (High Throughput Sequencing), z zastosowaniem dwóch platform: 454 firmy Roche oraz Genome Analyzer firmy Illumina/Solexa [38]. Obie platformy umożliwiają szybkie ustalanie milionów sekwencji, ale różnią się metodą przygotowania i namnażania bibliotek. W 2013 r. platforma 454 została wyparta przez nowe systemy firmy Illumina, a firma Roche zaprzestała stosowania systemu pirosekwencjonowania w 2016 r. [39].

\section{Współczesna metodologia badań nad kopalnym DNA}

Wraz z rozwojem technik NGS ugruntowały się dwa podejścia do sekwencjonowania kopalnego DNA. Pierwszym podejściem jest sekwencjonowanie wybranych fragmentów DNA po namnożeniu ich metodą PCR. Zaletą tego jest uzyskanie dużej liczby amplikonów, z których łatwo jest utworzyć bibliotekę NGS. Sekwencjonowanie amplikonów powinno się stosować, gdy badana sekwencja jest znana, a celem NGS jest zbadanie polimorfizmów pojedynczych nukleotydów, wykorzystywanych jako markery haplotypowania lub zidentyfikowanie substytucji nukleotydowych charakterystycznych dla danego osobnika [40]. Modyfikacją tego sposobu jest tzw. multipleks PCR jednocześnie wykorzystuje się kilka zestawów starterów, co pozwala na namnożenie wielu matryc w pojedynczej reakcji amplifikacji. Dzięki technice multipleks PCR możliwe było poznanie genomu mitochondrialnego i identyfikacja haplogrupy Ötziego - zwanego człowiekiem lodu (K10), którego dobrze zachowane szczątki odnaleziono w Alpach na granicy austriacko-włoskiej [41], oraz opisaniu zależności filogenetycznych jeleni szlachetnych zamieszkujących Półwysep Krymski oraz dróg ich migracji na terenie Eurazji [42]. Drugim sposobem sekwencjonowania kopalnego
DNA jest metoda „shotgun” polegająca na losowym sekwencjonowaniu całego genomu (whole genome shotgun sequencing) z pominięciem etapu mapowania klonów.

Shotgun jest wrażliwe na zanieczyszczenia egzogennym DNA, a zawartość endogennego DNA może być ograniczona przez aktywność degradacyjną mikroorganizmów. Sekwencjonowanie shotgun umożliwiło rekonstrukcję mitochondrialnego genomu mamuta włochatego [43]. Większą selektywność metody shotgun można uzyskać przez zastosowanie przynęt oligonukleotydowych, czyli fragmentów DNA komplementarnych do badanego fragmentu DNA i połączonych z kulkami magnetycznymi. Są to tzw. magnesy neodymowe umożliwiające selektywne izolowanie tylko tych fragmentów DNA, które połączyły się na zasadzie komplementarności z przynętami oligonukleotydowymi. Strategia shotgun razem z selektywnym wzbogacaniem biblioteki NGS za pomocą przynęt oligonukleotydowych umożliwiła prześledzenie procesu udomowienia kotów na terenie Europy od okresu wczesnego neolitu [44]. Mimo dużego prawdopodobieństwa na sekwencjonowanie artefaktów pochodzących $z$ egzogennego DNA metoda shotgun jest bardziej rekomendowana do analizy aDNA.

Sekwencjonowanie pierwszej i drugiej generacji utorowały drogę sekwencjonowaniu trzeciej generacji (TGS). Polega na sekwencjonowaniu pojedynczych nici DNA metodą opracowaną przez firmę Pacific Bioscience lub na wykorzystaniu technologii nanoporów oferowanych przez firmę Oxford Nonopore Technologies. Zastosowanie technologii TGS do pofragmentowanego aDNA jest dyskusyjne, gdyż ich użycie prowadzi do błędnego wstawiania nukleotydów do kopiowanych fragmentów DNA [45].

\section{Kto był pierwszym z nas?}

Pochodzenie człowieka jest tematem wielu publikacji zarówno z dziedziny archeologii jak i biologii molekularnej. Coraz powszechniejszym podejściem w rekonstrukcji pochodzenia i ewolucji człowieka staje się wykorzystanie kopalnego DNA i jego analiza technikami sekwencjonowania. Większość wyników potwierdza teorię zakładającą, że anatomicznie współczesny człowiek wywodzi się z Afryki [46]. Około $2 \mathrm{mln}$ lat temu najstarszy przedstawiciel rodzaju naczelnych, Homo erectus, rozpoczął swoją wędrówkę do Eurazji [47]. Około 700 tys. lat temu w Afryce pojawił się kolejny przedstawiciel naczelnych, Homo heidelbergensis [48], przodek współczesnych ludzi, ale także przedstawiciele dwóch wymarłych archaicznych form Homo sapiens neanderthalensis zamieszkującego Eurazję oraz nowo odkrytego Homo sapiens denisova żyjącego w Środkowo-Wschodniej Azji [49, 50]. $\mathrm{Na}$ podstawie badań genomu jądrowego neandertalczyka, którego szczątki odnaleziono w górach Ałtaj na Syberii, 
oszacowano czas odłączenia się $H$. sapiens neanderthalesis od anatomicznej współczesnych ludzi na okres 550-765 tys. lat. Analogiczne badania przeprowadzone dla denisowianina pozwoliły oszacować czas dywergencji linii ewolucyjnej neandertalczyków i denisowian na 381-473 tys. lat [51]. Wyodrębnienie się trzech linii ewolucyjnych nie spowodowało ich całkowitej separacji, a badania całych genomów wskazują, iż dochodziło do przepływu genów między przedstawicielami ludzi współczesnych, neandertalczykami i denisowianami. Porównanie genomów jądrowych wskazuje, że do wymiany genów dochodziło wielokrotnie między współczesnymi ludźmi a neandertalczykami w Europie i Azji, jednak wymiana nie odbyła się w Afryce. Natomiast denisowianie mieszali się z anatomicznie współczesnymi ludźmi w Azji i Oceanii, ale nie w Europie [52]. Stwierdzono, że natywne populacje Oceanii mają znacznie większą domieszkę genów denisowianina niż inne grupy etniczne. Ponadto u przodków tej grupy domieszka materiału genetycznego neandertalczyka jest znacznie starsza niż domieszka denisowianina [53]. Ostatnia wymiana genów między współczesnymi ludźmi a neandertalczykami odbyła się nie później niż 37 tys. lat temu. Świadczy o tym obecność 6-9\% domieszki genomu neandertalczyka w genomie wczesnego przedstawiciela Homo sapiens sapiens znalezionego w Pestera cu Oase w Rumunii (szczątki datowane na 24-37 tys. lat). Tak duża domieszka neandertalskiego DNA wskazuje, iż skrzyżowanie się osobników dwóch linii ewolucyjnych rodzaju Homo zdarzyło się 5-6 pokoleń wcześniej. Wraz z upływem czasu obserwuje się spadek zawartości neandertalskiego DNA w genomie współcześnie anatomicznych ludzi z $6 \%$ do obecnie $2 \%$, co może być interpretowane jako negatywny dobór naturalny związany ze zmniejszoną płodnością mieszańców [54] (ryc. 2).

Oprócz denisowianina oraz neandertalczyka niedawno odkryto nowego przedstawiciela rodzaju Homo. Szczątki Homo luzonensis odkryto w jaskini Callao na filipińskiej wyspie Luzon. Wiek kości tego hominida oszacowano na 67 tys. lat. Nie udało się natomiast wyizolować jego DNA. Przedstawiciele Homo luzonensis pochodzili prawdopodobnie od przedstawicieli Homo erectus, którzy około $1 \mathrm{mln}$ lat temu dotarli do Azji [56]. Szczątki neandertalczyków z terenu Polski ograniczone są do dwóch lokalizacji: Jaskini Ciemnej i Jaskini Stajnia. W Jaskini Ciemnej (Ojcowski Park Narodowy) odnaleziono siekacz żuchwy, ale podobnie jak z hominidem z Luzon nie wyizolowano z niego DNA [57]. Dużo lepiej zachowany ząb neandertalczyka (górny prawy drugi trzonowiec) odnaleziono w Jaskini Stajnia, w okolicy wsi Mirów (powiat Myszków). Datowanie zęba metodą ${ }^{14} \mathrm{C}$ dało wynik $22480 \pm 70$ lat. Niedoszacowanie rzeczywistego wieku było prawdopodobnie wynikiem zanieczyszczenia preparatu współczesnym węglem pochodzącym ze środków konserwujących zastosowanych po pracach wykopaliskowych. Udana izolacja DNA pozwoliła na odtworzenie genomu mitochondrialnego wskazującego na pokrewieństwo neandertalczyków z południowej Polski i Kaukazu. Dane uzyskane z obliczeń zegara molekularnego metodą maksymalnej parsymonii, poszerzone o informacje $z$ datowania metodą radiowęglową osadów sedymentacyjnych, wskazują, że badany ząb można datować na okres MIS 5a, czyli 71-82 tys. lat temu [58]. Szansa na odnalezienie szczątków na tyle dobrze zachowanych, że możliwe byłoby wyizolowanie dobrze zachowanego aDNA, jest niezwykle mała. Szacuje się, że 12 tys. lat temu, na przełomie paleolitu i neolitu, populacja zamieszkująca Ziemię liczyła 2 mln ludzi, a średnia gęstość zaludnienia w Europie wynosiła 0,1 osoby/ $\mathrm{km}^{2}$ [59]. Z tego wynika, że ogromne tereny były bezludne, a szczątki ludzkie bardzo trudne do odnalezienia.

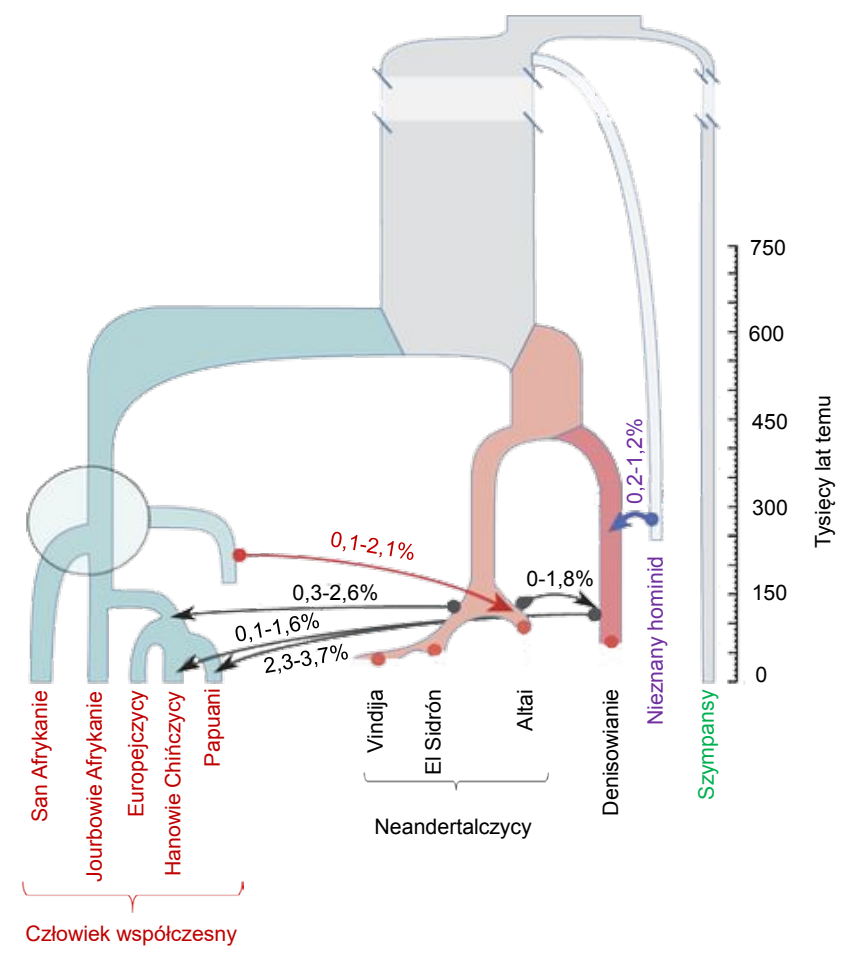

Rycina 2. Drzewo filogenetyczne archaicznych form rodzaju Homo i anatomicznie współczesnych ludzi (na podstawie [55]). Strzałki oznaczają kierunek przepływu genów między poszczególnymi populacjami. Jak dotąd zaobserwowano sześć dużych wymian genów, wliczając $w$ to domieszkę od nieznanych archaicznych hominidów do denisowian (niebieska strzałka). Czerwoną strzałką oznaczono przepływ genów od populacji anatomicznie współczesnych ludzi, którzy oddzielili się bardzo wcześnie od przodków dzisiejszych mieszkańców Afryki, do neandertalczyków. 


\section{Populacja mamuta włochatego na terenie Polski i Europy}

Badania nad kopalnym DNA pozwoliły prześledzić nie tylko historię powstania gatunku człowieka rozumnego (Homo sapiens sapiens), ale także odtworzyć strukturę filogenetyczną wymarłych gatunków zwierząt. Jednym z pierwszych rezultatów zastosowania technologii NGS w laboratoriach aDNA było odtworzenie genomu mamuta włochatego [60]. Mamut włochaty (Mammuthus primigenius) był największym przedstawicielem fauny zasiedlającym obszar rozciągający się od zachodniej Europy przez Azję po Amerykę Północną. Okres występowania tego ssaka obejmuje przedział czasu od plejstocenu po początek holocenu. Zbadanie sekwencji genomu mitochondrialnego wielu osobników mamuta włochatego pozwoliło na wyodrębnienie wyraźnie różniących się od siebie trzech linii monofiletycznych. Do pierwszej linii zaliczane są osobniki pochodzące z Ameryki Północnej i Eurazji. Linia druga obejmuje osobniki, których szczątki znaleziono tylko w środkowo-wschodniej Azji. W linii trzeciej znajdują się osobniki z endemicznej populacji europejskiej [61]. Największe zgrupowanie kości mamuta włochatego na terenie Polski znajduje się na wzgórzu św. Bronisławy przy ul. Hofmana (dawniej ul. Spadzistej) w Krakowie. W rejonie tym znajdowało się obozowisko myśliwych datowane na 24-25 tys. lat. Na stanowisku odnaleziono ponad 20000 szczątków kostnych, z których $90 \%$ należała do 86 mamutów włochatych. Ponadto odnaleziono szczątki lisów polarnych, nosorożców włochatych, niedźwiedzi brunatnych, wilków, koni i zajęcy [62]. Szczątki mamutów można też odnaleźć w innych częściach Polski. W miejscowości Gołąb (powiat puławski), na prawym brzegu Wisły odnaleziono fragmenty szczątków mamuta, którego przynależność gatunkową potwierdzono w Zakładzie Biologii Molekularnej Uniwersytetu Medycznego w Łodzi na podstawie analizy sekwencji fragmentów mitochondrialnego DNA. Datowanie radiowęglowe wskazało, iż osobnik ten żył w okresie późnego paleolitu (28,7 tys. lat), a zatem należał do pierwszej linii monofiletycznej. Potwierdzają to wcześniejsze badania wskazujące, iż osobniki z pierwszej linii przywędrowały do Europy około 32 tys. lat temu. Wydarzenie to zbiegło się w czasie $\mathrm{z}$ wyginięciem około 34 tys. lat temu Mammuthus primigenius zaliczanych do linii trzeciej [63, 64]. Nie ma jednak dowodów na to, iż populacje $z$ linii pierwszej i trzeciej występowały jednocześnie. Prawdopodobnie po wymarciu europejskiej populacji mamuta z linii III, obszar ten został zasiedlony przez syberyjską populację $z$ linii I. Zjawisko wymierania w tym samym okresie zaobserwowano dla populacji niedźwiedzi jaskiniowych $w$ dolinie rzeki Ach w południowych Niemczech [65]. Przyczyny zjawiska wymarcia linii trzeciej mamuta włochatego doszukiwać się można w pojawieniu się wczesnej kultury graweckiej lub $w$ regionalnych zmianach klimatu. Nie ma natomiast wiarygodnych doniesień, jak mamuty włochate z Syberii zdołały skolonizować Europę i przeżyć tam 15 tys. lat [61, 66].

Zespół badaczy z Japonii [67] podjął ważną próbę odtworzenia gatunku mamuta. Wyizolowali jądra komórkowe z mięśni mamuta włochatego, datowane na 28140 lat, i wprowadzili je do mysich oocytów. Oocyty nie przekształciły się jednak $w$ zygotę i nie rozpoczęły podziałów, co prawdopodobnie było spowodowane znaczną degradacją materiału genetycznego mamuta.

\section{Paleomikrobiologia i kopalne DNA}

Sekwencjonowanie nowej generacji stworzyło również wyjątkową okazję do poznania genomów starożytnych drobnoustrojów, zbadania ich wirulencji i dokładniejszego niż kiedykolwiek wcześniej zrozumienia procesu ich ewolucji. Badania NGS koncentrują się na rekonstrukcji historii wielu ludzkich patogenów biorących udział w pradawnych i historycznych epidemiach, takich jak dżuma, trąd czy gruźlica. Badania paleomikrobiologiczne prowadzone są również na mikroorganizmach komensalnych, czyli drobnoustrojach niepatogennych, występujących w jelitach i innych narządach człowieka.

Gruźlica jest jedną z najczęstszych chorób zakaźnych człowieka. Przypuszcza się, że u 9 mln ludzi rozwija się postać kliniczna choroby, z których umiera $2 \mathrm{mln}$ osób. Gruźlicę wywołuje kilka serotypów prątków gruźlicy (MTCB), które wywodzą się od jednego wspólnego przodka [68]. MTCB dzieli się na wiele linii filogenetycznych. Prawie wszystkie serotypy tej bakterii wywołujące gruźlicę u ludzi wywodzą się z Afryki i rozpowszechniły się w świecie około 60 tys. lat temu wraz z migracją Homo sapiens. Tylko 3 serotypy (środkowo-wschodnia Azja, wschodnia Afryka, Europa, Ameryka) wyodrębniły się po opuszczeniu przez człowieka Afryki, dlatego nazywane są „współczesnymi” [69]. Ostatni wspólny przodek (LUCA) wszystkich linii MTCB występował 70 tys. lat temu [68]. Badania nad aDNA Mycobacterium tuberculosis wskazują dwie możliwe drogi transmisji patogenu: pierwsza ze zwierząt na ludzi, druga w kierunku przeciwnym, z ludzi na zwierzęta. Odzwierzęce pochodzenie gruźlicy potwierdziły badania na szczątkach peruwiańskich Indian zmarłych około tysiąca lat temu. Zidentyfikowane patogeny należały do MTCB, przy czym były bliżej spokrewnione z Mycobacterium pinnipedii, której głównym gospodarzem są foki. Autorzy uważają, iż do zakażenia doszło w wyniku spożycia przez Indian zainfekowanego mięsa. Serotypy te występowały u człowieka w Ameryce Południowej do czasu, gdy zostały wyparte przez współczesne serotypy pochodzące z Europy i Afryki [70]. Obecnie bakterie M. pinnipedii mogą również zakażać ludzi, ale infekcje nie są przenoszone na 
innych ludzi [71]. Alternatywna droga transmisji z ludzi na zwierzęta została ostatecznie potwierdzona dzięki odkryciu w szczątkach amerykańskich bizonów, datowanych na 17 tys. lat, fragmentów DNA oraz biomarkerów lipidowych charakterystycznych dla $M$. tuberculosis, a nie dla prątka bydlęcego Mycobacterium bovis [72]. Teorię transmisji gruźlicy z ludzi na zwierzęta potwierdza to, że najstarszy aDNA $M$. bovis został zidentyfikowany $w$ epoce żelaza u syberyjskich pasterzy, znacznie później niż pierwsze zidentyfikowane kopalne DNA M. tuberculosis [73].

Badania nad aDNA prątka trądu (Mycobacterium leprae) rozszerzyły wiedzę o pochodzeniu, ewolucji i rozprzestrzenianiu się trądu na świecie. Analiza genomów tych bakterii $z$ okresu średniowiecza wskazuje na ich dużą zmienność genetyczną [74]. Pozwala to na zaproponowanie dwóch modeli wyjaśniających pochodzenie bakterii trądu w Europie. Pierwszy model zakłada, że M. leprae wywodzi się z Eurazji i stamtąd rozprzestrzenił się na resztę świata. Za tą teorią przemawia to, że większość europejskich średniowiecznych szczepów tego patogenu jest przodkami szczepów występujących współcześnie [74]. Drugi model zakłada, że pojawienie się różnych linii filogenetycznych bakterii $M$. lepraew Europie jestwynikiem ich napływuz różnych regionów świata na przełomie antyku i średniowiecza. Tezę potwierdza występowanie najstarszej linii filogenetycznej tej bakterii (szczególnie szczepu 3K) we współczesnych Chinach [75] jak i w średniowiecznych Węgrzech [55]. Brak danych genetycznych, uzyskanych na podstawie badań zarówno kopalnego jak i współczesnego DNA, z takich regionów jak Azja Środkowa i Bliski Wschód, nie pozwala na potwierdzenie żadnego $z$ powyższych modeli. W historii obserwowane były też jednoczesne infekcje zarówno $M$. leprae jak i M. tuberculosis. Szczątki osób współzakażonych trądem i gruźlicą pochodzą z Izraela (I w.), Egiptu (okres wpływów rzymskich), Węgier i Austrii (VII-XII w.) oraz Szwecji (IX-XIII w.) [76, 77]. Jednoczesne wystąpienie obu chorób mogło być przyczyną stopniowego zanikania trądu w Europie. Zmiany immunologiczne (obniżenie odporności) związane z lepromatyczną postacią trądu zwiększyły śmiertelność chorych na gruźlicę, a tym samym spowodowały stopniowy spadek liczby ognisk tej choroby w Europie [78, 79].

Jedną $z$ największych pandemii $w$ dziejach ludzkości była dżuma, która w latach 1347-1351 zabiła około $30 \mathrm{mln}$ ludzi, a jej skutkiem były daleko idące zmiany społeczno-polityczne w średniowiecznej Europie [80]. Dżuma, zwana też „czarną śmiercią", wywoływana jest przez pałeczkę dżumy (Yersinia pestis) i jest przenoszona przez pchły bytujące na chorych gryzoniach. W wyniku infekcji bakterie wędrują z krwią, zatrzymując się $w$ drenujących węzłach chłonnych. Pałeczki dżumy zasiedlając węzły chłonne, powodują ich nienaturalne powiększenie. Jest to charakterystyczny objaw dżumy dymieniczej. Płucna postać dżumy jest wynikiem zakażenia drogą kropelkową od zarażonej osoby, z pominięciem wektora zakażenia, jakim są pchły lub szczury. Trzecia postać dżumy to postać septyczna, u chorego rozwija się ogólnoustrojowa infekcja z pominięciem postaci dymieniczej [81, 82]. Najstarsze szczątki osób zmarłych na dżumę w Europie pochodzą z okresu brązu. Badania wskazują, iż pałeczka dżumy w tym okresie nie wykorzystywała pcheł jako wektora, gdyż nie miała jeszcze genów kodujących odpowiednie czynniki infekcyjne [83]. Dżuma dymienicza atakowała w dziejach świata trzykrotnie. Najstarsze doniesienie o tzw. pierwszej pandemii dżumy, określanej jako plaga Justyniana, wybuchła prawdopodobnie w północnej Afryce w połowie IV w. n.e. [84]. Druga pandemia dżumy wystąpiła w połowie XIV w. [85], trzecia pandemia, rozpoczęła się w XIX w. w chińskiej prowincji Yunnan i trwa do dzisiaj, w ciągle aktywnych ogniskach w Afryce, Azji i Ameryce Południowej [86]. Analiza filogenetyczna zrekonstruowanych genomów $Y$. pestis $\mathrm{z}$ VI w. wskazuje, że bakterie należały do wymarłego szczepu, ale blisko spokrewnionego z współcześnie występującym w Chinach, co sugeruje azjatyckie pochodzenie pierwszej pandemii [87, 88]. Pierwsze ogniska drugiej pandemii dżumy pojawiły się w regionie Dolnej Wołgi, na obszarze dzisiejszej Rosji i przez Półwysep Krymski przedostały się do Europy Południowej [89]. Badania fragmentów genomu pałeczek dżumy ujawniły wyraźne rozdzielenie filogenetyczne szczepów z początku i środka XIV w., co pozwoliło przypuszczać, że pandemia pojawiła się w Europie w niezależnych epizodach [90]. Analiza całych genomów bakterii $z$ północnej, południowej i zachodniej Europy wykazuje brak zmienności rekombinacyjnej Y. pestis w czasie trwania "czarnej śmierci”. Sugeruje to, iż dżuma napłynęła do Europy jedną falą, co potwierdza też jej szybkie rozpowszechnienie się na kontynencie [91]. Analiza genomu pałeczek dżumy od końca XIV do początku XVIII w. ujawnia wyodrębnienie się dwóch europejskich linii filogenetycznych. Pierwsza linia przetrwała do czasów współczesnych, dając początek trzeciej pandemii. Druga linia wywołała epidemię dżumy w Niemczech (XVI w.) oraz we Francji (XVIII w.). Brak jest doniesień literaturowych o pojawieniu się jej współcześnie [92].

\section{Wkład Polaków w rozwój wiedzy o kopalnym DNA}

Niewątpliwie najbliższe lata przyniosą wiele niezwykłych i ważnych odkryć z dziedziny kopalnego DNA, które będą skutkiem ciągłego udoskonalania technik sekwencjonowania DNA, jak i wkładu naukowców zajmujących się tą dziedziną. Na szczególne uznanie zasługuje wkład polskich uczonych: poza wcześniej wspomnianymi pracami $[42,44]$ wywodzącymi się z Laboratorium Paleogenetyki i Genetyki Konserwatorskiej wchodzącego w skład Centrum Nowych Technologii Uniwersytetu Warszawskiego, warto zwrócić uwagę na 
publikację opisującą genomy Y. pestis, pochodzących ze szczątków odnalezionych m.in. w średniowiecznym Gdańsku [93]. Badania filogenetyczne struktury genomu pałeczek dżumy z Gdańska ujawniły podobieństwo bakterii do tych, które wywoływały pandemię czarnej śmierci w Europie od XV do XVIII w. Po raz pierwszy badaczom powiodło się powiązanie DNA Y. pestis ze średniowiecznymi szczątkami zwierząt, a zwłaszcza szczurów. Liczne badania genetycznego pochodzenia Słowian prowadzone były w Zakładzie Biologii Molekularnej Uniwersytetu Medycznego w Łodzi. W niedawnej pracy [94] prześledzono haplogrupy mtDNA u osobników pochowanych na średniowiecznym cmentarzysku w tzw. grobach komorowych z miejscowości Kałdus, które są charakterystycznym pochówkiem skandynawskim. Otrzymane wyniki wykazały jednak brak obecności haplogrupy I, uważanej za charakterystyczną dla Skandynawii tego okresu. Jednak oznaczono trzy haplogrupy (T2b4a, HV, J2b1a1a) na wyżej wymienionym cmentarzysku, takie same jak w średniowiecznej Norwegii, przy czym haplogrupy te bardzo rzadko występują we współczesnej Europie. Podsumowując, na średniowiecznych cmentarzyskach w Kałdusie i Napolu [95] 17\% haplotypów (rozważając tylko te najrzadsze w Europie) była identyczna z tymi odnalezionymi na średniowiecznych cmentarzyskach w Norwegii i Danii. Wyniki pracy nie pozwoliły na potwierdzenie tezy o skandynawskim pochodzeniu średniowiecznych polskich elit. Zaobserwowano natomiast inną zależność. W pochówkach typowych dla Słowian częściej występowały haplogrupy charakterystyczne dla Europy Północnej, niż w grobach komorowych. Ważna praca została opublikowana przez badaczy z poznańskich uczelni [96]. Autorzy przeprowadzili obszerną analizę mikrobiomu zasiedlającego ludzkie kości, przechowywanych w warunkach muzealnych, jak i pochodzących bezpośrednio z wykopalisk. Materiał archeologiczny (161 zębów z 7 stanowisk archeologicznych) pochodzi z obszaru Polski i datowany jest na 100-1200 r. n.e. Najliczniejszą grupą zaobserwowanych mikroorganizmów były bakterie i archeony stanowiące $76,4 \%$ wszystkich odczytów, 23,4\% wirusy i wiroidy, a pozostałe $0,2 \%$ protisty i grzyby. Udział poszczególnych typów mikroorganizmów różnił się znamiennie między próbkami, nie zaobserwowano jednak statystycznie istotnych zmian w położeniu stanowiska archeologicznego, wieku materiału ani warunków przechowywania. Istotną obserwacją jest to, że przechowywanie materiału kostnego w warunkach muzealnych (czyszczenie, mycie) nie ma istotnego wpływu na skład mikroorganizmów zamieszkujących taką niszę. Wśród zidentyfikowanych klas bakterii największy udział miały promieniowce jak Brevibacterium czy Kribella, które występują głównie w środowisku glebowym i wodnym. W niektórych próbkach zidentyfikowano też bakterie charakterystyczne dla człowieka, tj. bakterie jamy ustnej (Corynebacterium, Eubacterium, Tannerella), układu pokarmowego (Escherichia, Neisseria) oraz patogeny (Bordetella, Bartonella, Stenotrophomonas, Clostridium). Wśród wirusów dominowały głównie patogeny roślinne, przy czym zaobserwowano dwa wirusy RNA (wirus mozaiki Dasheen - 58\% wszystkich zidentyfikowanych wirusów oraz wirus wyki - $26,7 \%$ wszystkich zidentyfikowanych wirusów). Uwzględniając to, że metodyka przygotowania biblioteki jednoniciowego DNA w NGS nie zawierała etapu odwrotnej transkrypcji, autorzy ostrożnie wnioskują, że identyfikacja wirusów RNA może być wynikiem:

- przypadkowej aktywności bliżej nieokreślonej środowiskowej odwrotnej transkryptazy,

- nieswoistej aktywności polimerazy DNA, która w dużym stężeniu może wykorzystać RNA jako matrycę lub

- błędnego mapowania niektórych odczytów NGS do genomów referencyjnych wirusów RNA, co prowadzi do błędnej klasyfikacji drobnoustrojów.

Badania nad starzeniem się DNA wykazały, że bakterie środowiskowe mają najmniej zmian charakterystycznych dla kopalnego DNA w przeciwieństwie do gatunków bakterii komensalnych człowieka, wykazujących liczne substytucje $\mathrm{C} / \mathrm{T}, \mathrm{G} / \mathrm{A}$ typowe dla aDNA.

\section{Podsumowanie}

Powyższe przykłady w sposób jednoznaczny wykazują, że zbadanie swoistej kolejności zasad azotowych w pierwszorzędowej strukturze DNA pozyskanych z próbek, z wykopalisk czy eksponatów muzealnych, może zasadniczo rozszerzyć wiedzę na temat obrazu życia w przeszłości. Poszerzenie wiedzy o mechanizmach ewolucji transmisji drobnoustrojów może w przyszłości skuteczniej zapobiegać epidemiom i pandemiom, z jakimi mierzy się światowa medycyna. Wiedza płynąca ze śledzenia zmienności genetycznej dawnych populacji zwierząt i ich migracji pozwoli przewidywać losy współcześnie żyjących zwierząt, co jest szczególnie istotne w przypadku gatunków zagrożonych wyginięciem. Wierzymy, że najbliższe lata przyniosą wiele ważnych odkryć, wzbogacając zarówno nauki biologiczne jak i historyczne. Czytelnikowi chcącemu poszerzyć wiedzę na temat kopalnego DNA, autorzy polecają książkę która 
ukazała się w 2020 r. Ancient DNA and Genetic Engineering, nakładem Wydawnictw Uniwersytetu Warszawskiego [97].

\section{Wykaz skrótów}

aDNA - kopalny DNA (ancient DNA), LUCA - ostatni wspólny przodek (Last Universal Common Ancestor), MIS - morskie stadia izotopowe (Marine Isotope Stage), MTBC - zespół bakterii Mycobacterium tuberculosis (Mycobacterium tuberculosis complex of bacteria), mtDNA - mitochondrialny DNA, NGS - sekwencjonowanie drugiej generacji (Next-Generation Sequencing), PCR - łańcuchowa reakcja polimerazy (Polymerase Chain Reaction), TGS sekwencjonowanie trzeciej generacji (Third-Generation Sequencing), TK - tomografia komputerowa.

\section{Finansowanie}

Praca powstała dzięki wsparciu finansowemu Narodowego Centrum Nauki, nr grantu: 2017/01/X/HS3/01876.

\section{Konflikt interesów}

Autorzy deklarują brak potencjalnych konfliktów interesów.

\section{Piśmiennictwo}

[1] Chang H.H., Pannunzio N.R., Adachi N., Lieber M.R.: Non-homologous DNA end joining and alternative pathways to double-strand break repair. Nat. Rev. Mol. Cell Biol., 2017; 18: 495-506

[2] Surova O., Zhivotovsky B.: Various modes of cell death induced by DNA damage. Oncogene, 2013; 32: 3789-3797

[3] De Zio D., Cianfanelli V., Cecconi F.: New insights into the link between DNA damage and apoptosis. Antioxid. Redox. Signal., 2013; 19: 559-571

[4] Pääbo S.: Ancient DNA: Extraction, characterization, molecular cloning, and enzymatic amplification. Proc. Natl.Acad. Sci. USA, 1989; 86: 1939-1943

[5] Pääbo S., Poinar H., Serre D., Jaenicke-Despres V., Hebler J., Rohland N., Kuch M., Krause J., Vigilant L., Hofreiter M.: Genetic analyses from ancient DNA. Annu. Rev. Genet., 2004; 38: 645-679

[6] Briggs A.W., Stenzel U., Johnson P.L., Green R.E., Kelso J., Prüfer K., Meyer M., Krause J., Ronan M.T., Lachmann M., Pääbo S.: Patterns of damage in genomic DNA sequences from a Neandertal. Proc. Natl.Acad. Sci. USA, 2007; 104: 14616-14621

[7] Orlando L., Ginolhac A., Raghavan M., Vilstrup J., Rasmussen M., Magnussen K., Steinmann K.E., Kapranov P., Thompson J.F.,
Zazula G. i wsp.: True single-molecule DNA sequencing of a Pleistocene horse bone. Genome Res., 2011; 21: 1705-1719

[8] Overballe-Petersen S., Orlando L., Willerslev E.: Next-generation sequencing offers new insights into DNA degradation. Trends Biotechnol., 2012; 30: 364-368

[9] Handt O., Höss M., Krings M., Pääbo S.: Ancient DNA: Methodological challenges. Experientia, 1994; 50: 524-529

[10] Hofreiter M., Jaenicke V., Serre D., von Haeseler A., Pääbo S.: DNA sequences from multiple amplifications reveal artifacts induced by cytosine deamination in ancient DNA. Nucleic Acids Res., 2001; 29: 4793-4799

[11] Gilbert M.T., Willerslev E., Hansen A.J., Barnes I., Rudbeck L., Lynnerup N., Cooper A.: Distribution patterns of postmortem damage in human mitochondrial DNA. Am. J. Hum. Genet., 2003; 72: $32-47$

[12] Hansen A.J., Mitchell D.L., Wiuf C., Paniker L., Brand T.B., Binladen J., Gilichinsky D.A., Rønn R., Willerslev E.: Crosslinks rather than strand breaks determine access to ancient DNA sequences from frozen sediments. Genetics, 2006; 173: 1175-1179

[13] Allentoft M.E., Collins M., Harker D., Haile J., Oskam C.L., Hale M.L., Campos P.F., Samaniego J.A., Gilbert M.T., Willerslev E., Zhang G., Scofield R.P., Holdaway R.N., Bunce M.: The half-life of DNA in bone: Measuring decay kinetics in 158 dated fossils. Proc. Biol. Sci. R. Soc. B, 2012; 279: 4724-4733

[14] van der Valk T., Pečnerová P., Díez-del-Molino D., Bergström A., Oppenheimer J., Hartmann S., Xenikoudakis G., Thomas J.A., Dehasque M., Sağlıcan E. i wsp.: Million-year-old DNA sheds light on the genomic history of mammoths. Nature, 2021; 591: 265-269

[15] Sawyer S., Krause J., Guschanski K., Savolainen V., Pääbo S.: Temporal patterns of nucleotide misincorporations and DNA fragmentation in ancient DNA. PLoS One, 2012; 7: e34131

[16] Peyrégne S., Prüfer K.: Present-day DNA contamination in ancient DNA datasets. Bioessays, 2020; e2000081

[17] Gilbert M.T., Bandelt H.J., Hofreiter M., Barnes I.: Assessing ancient DNA studies. Trends Ecol. Evol., 2005; 20: 541-544

[18] Raghavan M., Skoglund P., Graf K.E., Metspalu M., Albrechtsen A., Moltke I., Rasmussen S., Stafford T.W.Jr., Orlando L., Metspalu E. i wsp.: Upper Palaeolithic Siberian genome reveals dual ancestry of Native Americans. Nature, 2014; 505: 87-91

[19] Green R.E., Krause J., Briggs A.W., Maricic T., Stenzel U., Kircher M., Patterson N., Li H., Zhai W., Fritz M.H. i wsp.: A draft sequence of the Neandertal genome. Science, 2010; 328: 710-722

[20] Poinar H.N., Schwarz C., Qi J., Shapiro B., Macphee R.D., Buigues B., Tikhonov A., Huson D.H., Tomsho L.P., Auch A., Rampp M., Miller W., Schuster S.C.: Metagenomics to paleogenomics: Large-scale sequencing of mammoth DNA. Science, 2006; 311: 392-394

[21] Haile J., Holdaway R., Oliver K., Bunce M., Gilbert M.T., Nielsen R., Munch K., Ho S.Y., Shapiro B., Willerslev E.: Ancient DNA chronology within sediment deposits: Are paleobiological reconstructions possible and is DNA leaching a factor? Mol. Biol. Evol., 2007; 24: 982-989 
[22] Witas H.W.: O rygorach metodycznych analizowania kopalnego DNA i skutkach ich nieprzestrzegania. Archeol. Polski, 2015; 60: 164-177

[23] Willerslev E., Cooper A.: Ancient DNA. Proc. Biol. Sci. R. Soc. B, 2005; 272: 3-16

[24] Barta J.L., Monroe C., Kemp B.M.: Further evaluation of the efficacy of contamination removal from bone surfaces. Forensic Sci. Int., 2013; 231: 340-348

[25] Malmström H., Svensson E.M., Gilbert M.T., Willerslev E., Götherström A., Holmlund G.: More on contamination: The use of asymmetric molecular behavior to identify authentic ancient human DNA. Mol. Biol. Evol., 2007; 24: 998-1004

[26] Sirak K.A., Fernandes D.M., Cheronet O., Novak M., Gamarra B., Balassa T., Bernert Z., Cséki A., Dani J., Gallina J.Z. i wsp.: A minimally-invasive method for sampling human petrous bones from the cranial base for ancient DNA analysis. BioTechniques, 2017; 62: 283-289

[27] Alberti F., Gonzalez J., Paijmans J.L., Basler N., Preick M., Henneberger K., Trinks A., Rabeder G., Conard N.J., Münzel S.C. i wsp.: Optimized DNA sampling of ancient bones using computed tomography scans. Mol. Ecol. Resour., 2018; 18: 1196-1208

[28] Lautenschlager S.: Reconstructing the past: Methods and techniques for the digital restoration of fossils. R. Soc. Open Sci., 2016; 3: 160342

[29] Higuchi R., Bowman B., Freiberger M., Ryder O.A., Wilson A.C.: DNA sequences from the quagga, an extinct member of the horse family. Nature, 1984; 312: 282-284

[30] Pääbo S.: Molecular cloning of Ancient Egyptian mummy DNA. Nature, 1985; 314: 644-645

[31] Woodward S.R., Weyand N.J., Bunnell M.: DNA sequence from Cretaceous period bone fragments. Science, 1994; 266: 12291232

[32] Vreeland R.H., Rosenzweig W.D., Powers D.W.: Isolation of a 250 million-year-old halotolerant bacterium from a primary salt crystal. Nature, 2000; 407: 897-900

[33] Krings M., Geisert H., Schmitz R.W., Krainitzki H., Pääbo S.: DNA sequence of the mitochondrial hypervariable region II from the Neandertal type specimen. Proc. Natl.Acad. Sci. USA, 1999; 96: 5581-5585

[34] Krings M., Stone A., Schmitz R.W., Krainitzki H., Stoneking M., Pääbo S.: Neandertal DNA sequences and the origin of modern humans. Cell, 1997; 90: 19-30

[35] Nesheva D.: Aspects of ancient mitochondrial DNA analysis in different populations for understanding human evolution. Balkan J. Med. Genet., 2014; 17: 5-14

[36] Krause J., Dear P.H., Pollack J.L., Slatkin M., Spriggs H., Barnes I., Lister A.M., Ebersberger I., Pääbo S., Hofreiter M.: Multiplex amplification of the mammoth mitochondrial genome and the evolution of Elephantidae. Nature, 2006; 439: 724-727

[37] Zeyland J., Wolko L., Bocianowski J., Szalata M., Slomski R., Dzieduszycki A.M., Ryba M., Przystałowska H., Lipiński D.: Com- plete mitochondrial genome of wild aurochs (Bos primigenius) reconstructed from ancient DNA. Pol. J. Vet. Sci., 2013; 16: 265-273

[38] Millar C.D., Huynen L., Subramanian S., Mohandesan E., Lambert D.M.: New developments in ancient genomics. Trends Ecol. Evol., 2008; 23: 386-393

[39] Hollmer M.: Roche to close 454 Life Sciences as it reduces gene sequencing focus. https://www.fiercebiotech.com/medical-devices/roche-to-close-454-life-sciences-as-it-reduces-gene-sequencing-focus (08.04.2021)

[40] Lalueza-Fox C., Gigli E., de la Rasilla M., Fortea J., Rosas A., Bertranpetit J., Krause J.: Genetic characterization of the ABO blood group in Neandertals. BMC Evol. Biol., 2008; 8: 342

[41] Ermini L., Olivieri C., Rizzi E., Corti G., Bonnal R., Soares P., Luciani S., Marota I., De Bellis G., Richards M.B., Rollo F.: Complete mitochondrial genome sequence of the Tyrolean Iceman. Curr. Biol., 2008; 18: 1687-1693

[42] Doan K., Mackiewicz P., Sandoval-Castellanos E., Stefaniak K., Ridush B., Dalén L., Węgleński P., Stankovic A.: The history of Crimean red deer population and Cervus phylogeography in Eurasia. Zool. J. Linnean Soc., 2017; 183: 208-225

[43] Miller W., Drautz D.I., Ratan A., Pusey B., Qi J., Lesk A.M., Tomsho L.P., Packard M.D., Zhao F., Sher A. i wsp.: Sequencing the nuclear genome of the extinct woolly mammoth. Nature, 2008; 456: 387-390

[44] Baca M., Popović D., Panagiotopoulou H., Marciszak A., Krajcarz M., Krajcarz M.T., Makowiecki D., Węgleński P., Nadachowski A.: Human-mediated dispersal of cats in the Neolithic Central Europe. Heredity, 2018; 121: 557-563

[45] Hofreiter M., Paijmans J.L., Goodchild H., Speller C.F., Barlow A., Fortes G.G., Thomas J.A., Ludwig A., Collins M.J.: The future of ancient DNA: Technical advances and conceptual shifts. Bioessays, 2015; 37: 284-293

[46] Galway-Witham J., Stringer C.: How did Homo sapiens evolve? Science, 2018; 360: 1296-1298

[47] Antón S.C.: Natural history of Homo erectus. Am. J. Phys. Anthropol., 2003; 122: 126-170

[48] Meyer M., Arsuaga J.L., de Filippo C., Nagel S., Aximu-Petri A., Nickel B., Martínez I., Gracia A., Bermúdez de Castro J.M., Carbonell E. i wsp.: Nuclear DNA sequences from the Middle Pleistocene Sima de los Huesos hominins. Nature, 2016; 531: 504-507

[49] Meyer M., Kircher M., Gansauge M.T., Li H., Racimo F., Mallick S., Schraiber J.G., Jay F., Prüfer K., de Filippo C. i wsp.: A highcoverage genome sequence from an archaic Denisovan individual. Science, 2012; 338: 222-226

[50] Zhang D., Xia H., Chen F., Li B., Slon V., Cheng T., Yang R., Jacobs Z., Dai Q., Massilani D. i wsp.: Denisovan DNA in late Pleistocene sediments from Baishiya Karst Cave on the Tibetan Plateau. Science, 2020; 370: 584-587

[51] Prüfer K., Racimo F., Patterson N., Jay F., Sankararaman S., Sawyer S., Heinze A., Renaud G., Sudmant P.H., de Filippo C. i wsp.: The complete genome sequence of a Neanderthal from the Altai Mountains. Nature, 2014; 505: 43-49 
[52] Kuhlwilm M., Gronau I., Hubisz M.J., de Filippo C., Prado-Martinez J., Kircher M., Fu Q., Burbano H.A., Lalueza-Fox C., de la Rasilla M. i wsp.: Ancient gene flow from early modern humans into Eastern Neanderthals. Nature, 2016; 530: 429-433

[53] Sankararaman S., Mallick S., Patterson N., Reich D.: The combined landscape of Denisovan and Neanderthal ancestry in present-day humans. Curr. Biol., 2016; 26: 1241-1247

[54] Fu Q., Posth C., Hajdinjak M., Petr M., Mallick S., Fernandes D., Furtwängler A., Haak W., Meyer M., Mittnik A. i wsp.: The genetic history of Ice Age Europe. Nature, 2016; 534: 200-205

[55] Mendum T.A., Taylor G.M., Donoghue H.D., Wu H., Szalontai C., Marcsik A., Molnár E., Pálfi G., Stewart G.R.: The genome sequence of a SNP type $3 \mathrm{~K}$ strain of Mycobacterium leprae isolated from a seventh-century Hungarian case of lepromatous leprosy. Int. J. Osteoarchaeol., 2018; 28: 439-447

[56] Détroit F., Mijares A.S., Corny J., Daver G., Zanolli C., Dizon E., Robles E., Grün R., Piper P.J.: A new species of Homo from the late Pleistocene of the Philippines. Nature, 2019; 568: 181-186

[57] Willman J.C., Ginter B., Hernando R., Lozano M., Sobczyk K., Stefański D., Szczepanek A., Wertz K., Wojtal P., Zając M., Zarzecka-Szubińska K., Valde-Nowak P.: Paleobiology and taphonomy of a middle Paleolithic Neandertal tooth from Ciemna Cave, Southern Poland. J. Paleo. Arch., 2019; 2: 359-377

[58] Picin A., Hajdinjak M., Nowaczewska W., Benazzi S., Urbanowski M., Marciszak A., Fewlass H., Socha P., Stefaniak K., Żarski M. i wsp.: New perspectives on Neanderthal dispersal and turnover from Stajnia Cave (Poland). Sci. Rep., 2020; 10: 14778

[59] Klein Goldewijk K., Beusen A., Janssen P.: Long-term dynamic modeling of global population and built-up area in a spatially explicit way: HYDE 3.1. Holocene, 2010; 20: 565-573

[60] Stiller M., Knapp M., Stenzel U., Hofreiter M., Meyer M.: Direct multiplex sequencing (DMPS) - a novel method for targeted highthroughput sequencing of ancient and highly degraded DNA. Genome Res., 2009; 19: 1843-1848

[61] Palkopoulou E., Dalén L., Lister A.M., Vartanyan S., Sablin M., Sher A., Edmark V.N., Brandström M.D., Germonpré M., Barnes I., Thomas J.A.: Holarctic genetic structure and range dynamics in the woolly mammoth. Proc. R. Soc. B, 2013; 280: 20131910

[62] Drucker D.G., Rivals F., Münzel S.C., Bocherens H.: Stable isotope and microwear investigation on the mammoth (Mammuthus primigenius) of Kraków Spadzista: Insights into diet and environment. W: A Gravettian Site in Southern Poland - Kraków Spadzista, red.: P. Wojtal, J.Wilczyński, G.Haynes. ISEA PAS, Kraków 2015, 189-202

[63] Fellows Yates J.A., Drucker D.G., Reiter E., Heumos S., Welker F., Münzel S.C., Wojtal P., Lázničková-Galetová M., Conard N.J., Herbig A. i wsp.: Central European woolly mammoth population dynamics: Insights from late Pleistocene mitochondrial genomes. Sci Rep, 2017; $7: 17714$

[64] Palkopoulou E., Lipson M., Mallick S., Nielsen S., Rohland N., Baleka S., Karpinski E., Ivancevic A.M., To T.H., Kortschak R.D. i wsp.: A comprehensive genomic history of extinct and living elephants. Proc. Natl.Acad. Sci. USA, 2018; 115: E2566-E2574

[65] Hofreiter M., Münzel S., Conard N.J., Pollack J., Slatkin M., Weiss G., Pääbo S.: Sudden replacement of cave bear mitochondrial DNA in the late Pleistocene. Curr. Biol., 2007; 17: R122-R123

[66] Pesesse D., Flas D.: The Maisierian, at the edge of the Gravettian. Proc. Prehist. Soc., 2012; 78: 95-109

[67] Yamagata K., Nagai K., Miyamoto H., Anzai M., Kato H., Miyamoto K., Kurosaka S., Azuma R., Kolodeznikov I.I., Protopopov A.V. i wsp.: Signs of biological activities of 28,000-year-old mammoth nuclei in mouse oocytes visualized by live-cell imaging. Sci. Rep., 2019; 9: 4050

[68] Comas I., Coscolla M., Luo T., Borrell S., Holt K.E., Kato-Maeda M., Parkhill J., Malla B., Berg S., Thwaites G. i wsp.: Out-of-Africa migration and Neolithic coexpansion of Mycobacterium tuberculosis with modern humans. Nat. Genet., 2013; 45: 1176-1182

[69] Hershberg R., Lipatov M., Small P.M., Sheffer H., Niemann S., Homolka S., Roach J.C., Kremer K., Petrov D.A., Feldman M.W., Gagneux S.: High functional diversity in Mycobacterium tuberculosis driven by genetic drift and human demography. PLoS Biol., 2008; 6: e311

[70] Hershkovitz I., Donoghue H.D., Minnikin D.E., May H., Lee O.Y., Feldman M., Galili E., Spigelman M., Rothschild B.M., Bar-Gal G.K.: Tuberculosis origin: The Neolithic scenario. Tuberculosis, 2015; 95: S122-S126

[71] Achtman M.: How old are bacterial pathogens? Proc. R. Soc. B, 2016; 283: 20160990

[72] Lee O.Y., Wu H.H., Donoghue H.D., Spigelman M., Greenblatt C.L., Bull I.D., Rothschild B.M., Martin L.D., Minnikin D.E., Besra G.S.: Mycobacterium tuberculosis complex lipid virulence factors preserved in the 17,000-year-old skeleton of an extinct bison, Bison antiquus. PLoS One, 2012; 7: e41923

[73] Taylor G.M., Murphy E., Hopkins R., Rutland P., Chistov Y.: First report of Mycobacterium bovis DNA in human remains from the Iron Age. Microbiology, 2007; 153: 1243-1249

[74] Schuenemann V.J., Avanzi C., Krause-Kyora B., Seitz A., Herbig A., Inskip S., Bonazzi M., Reiter E., Urban C., Dangvard Pedersen D. i wsp.: Ancient genomes reveal a high diversity of Mycobacterium leprae in medieval Europe. PLoS Pathog., 2018; 14: e1006997

[75] Yuan Y., Wen Y., You Y., Xing Y., Li H., Weng X., Wu N., Liu S., Zhang S., Zhang W., Zhang Y.: Characterization of Mycobacterium leprae genotypes in China - Identification of a new polymorphism C251T in the 16S rRNA gene. PLoS One, 2015; 10: e0133268

[76] Donoghue H.D., Marcsik A., Matheson C., Vernon K., Nuorala E., Molto J.E., Greenblatt C.L., Spigelman M.: Co-infection of Mycobacterium tuberculosis and Mycobacterium leprae in human archaeological samples: A possible explanation for the historical decline of leprosy. Proc. Biol. Sci. R. Soc. B, 2005; 272: 389-394

[77] Donoghue H.D., Michael Taylor G., Marcsik A., Molnár E., Pálfi G., Pap I., Teschler-Nicola M., Pinhasi R., Erdal Y.S., Velemínsky P. i wsp.: A migration-driven model for the historical spread of 
leprosy in medieval Eastern and Central Europe. Infect. Genet. Evol., 2015; 31: 250-256

[78] Donoghue H.D.: Tuberculosis and leprosy associated with historical human population movements in Europe and beyond - an overview based on mycobacterial ancient DNA. Ann. Hum. Biol., 2019; 46: 120-128

[79] Hohmann N., Voss- Böhme A.: The epidemiological consequences of leprosy-tuberculosis co-infection. Math. Biosci., 2013; 241: 225-237

[80] Mordechai L., Eisenberg M., Newfield T.P., Izdebski A., Kay J.E., Poinar H.: The Justinianic Plague: An inconsequential pandemic? Proc. Natl. Acad. Sci. USA, 2019; 116: 25546-25554

[81] Prokopowicz D.: Medycyna geograficzna ze szczególnym uwzględnieniem medycyny tropikalnej. Choroby zakaźne i pasożytnicze, red.: J. Cianciara, J. Juszczyk. Czelej Sp. z o.o., Lublin 2007, 436

[82] Sebbane F., Gardner D., Long D., Gowen B.B., Hinnebusch B.J.: Kinetics of disease progression and host response in a rat model of bubonic plague. Am. J. Pathol., 2005; 166: 1427-1439

[83] Rasmussen S., Allentoft M.E., Nielsen K., Orlando L., Sikora M., Sjögren K.G., Pedersen A.G., Schubert M., Van Dam A., Kapel C.M. i wsp.: Early divergent strains of Yersinia pestis in Eurasia 5,000 years ago. Cell, 2015; 163: 571-582

[84] Sarris P.: The Justinianic plague: Origins and effects. Contin. Change, 2002; 17: 169-182

[85] Bos K.I., Schuenemann V.J., Golding G.B., Burbano H.A., Waglechner N., Coombes B.K., McPhee J.B., DeWitte S.N., Meyer M., Schmedes S. i wsp.: A draft genome of Yersinia pestis from victims of the Black Death. Nature, 2011; 478: 506-510

[86] Drancourt M., Raoult D.: Molecular history of plague. Clin. Microbiol. Infect., 2016; 22: 911-915

[87] Feldman M., Harbeck M., Keller M., Spyrou M.A., Rott A., Trautmann B., Scholz H.C., Päffgen B., Peters J., McCormick M. i wsp.: A high-coverage Yersinia pestis genome from a sixth-century Justinianic plague victim. Mol. Biol. Evol., 2016; 33: 2911-2923

[88] Wagner D.M., Klunk J., Harbeck M., Devault A., Waglechner N., Sahl J.W., Enk J., Birdsell D.N., Kuch M., Lumibao C. i wsp.: Yersinia pestis and the Plague of Justinian 541-543 AD: A genomic analysis. Lancet Infect. Dis., 2014; 14: 319-326
[89] Gładykowska-Rzeczycka J.J.: Paleoepidemiologia-archeoepidemie. W: Epidemie, klęski, wojny, red.: W. Dzieduszycki, J. Wrzesiński. Stowarzyszenie Naukowe Archeologów Polskich, Poznań 2008, 44-45

[90] Haensch S., Bianucci R., Signoli M., Rajerison M., Schultz M., Kacki S., Vermunt M., Weston D.A., Hurst D., Achtman M. i wsp.: Distinct clones of Yersinia pestis caused the black death. PLoS Pathog., 2010; 6: e1001134

[91] Namouchi A., Guellil M., Kersten O., Hänsch S., Ottoni C., Schmid B.V., Pacciani E., Quaglia L., Vermunt M., Bauer E.L. i wsp.: Integrative approach using Yersinia pestis genomes to revisit the historical landscape of plague during the Medieval Period. Proc. Natl.Acad. Sci. USA, 2018; 115: E11790-E11797

[92] Spyrou M.A., Tukhbatova R.I., Feldman M., Drath J., Kacki S., Beltrán de Heredia J., Arnold S., Sitdikov A.G., Castex D., Wahl J. i wsp.: Historical Y. pestis genomes reveal the European Black Death as the source of ancient and modern plague pandemics. Cell Host Microbe, 2016; 19: 874-881

[93] Morozova I., Kasianov A., Bruskin S., Neukamm J., Molak M., Batieva E., Pudło A., Rühli F.J., Schuenemann V.J.: New ancient Eastern European Yersinia pestis genomes illuminate the dispersal of plague in Europe. Philos. Trans. R. Soc. Lond. B Biol. Sci., 2020; 375: 20190569

[94] Płoszaj T., Jedrychowska-Dańska K., Zamerska A., Lewandowska M., Bojarski J., Chudziak W., Drozd-Lipinska A., Robaszkiewicz A., Witas H.W.: Analysis of maternal lineage structure of individuals from chamber graves placed in medieval cemetery in Kaldus, Central Poland. Homo, 2020; 71: 43-50

[95] Płoszaj T., Jędrychowska-Dańska K., Masłowska A., Kozłowski T., Chudziak W., Bojarski J., Robaszkiewicz A., Witas H.W.: Analysis of medieval mtDNA from Napole cemetery provides new insights into the early history of Polish state. Ann. Hum. Biol., 2017; 44: $91-94$

[96] Philips A., Stolarek I., Kuczkowska B., Juras A., Handschuh L., Piontek J., Kozlowski P., Figlerowicz M.: Comprehensive analysis of microorganisms accompanying human archaeological remains. Gigascience, 2017; 6: 1-13

[97] Węgleński P.: Ancient DNA and Genetic Engineering. Wydawnictwa Uniwersytetu Warszawskiego, Warszawa 2020 